\title{
Effect of parity on metabolic and oxidative stress profiles in Holstein dairy cows
}

\author{
Shimaa G. Yehia1 ${ }^{1}$, Eman S. Ramadan ${ }^{1}$ (D), Eissa A. Megahed² and Noha Y. Salem ${ }^{1}$ (D) \\ 1. Department of Internal Medicine and Infectious Diseases, Faculty of Veterinary Medicine, Cairo University, Giza, Egypt; \\ 2. Veterinary Medicine Directorate - Giza, El Haram, Giza, Egypt. \\ Corresponding author: Shimaa G. Yehia, e-mail: shimaaghanem2013@gmail.com \\ Co-authors: ESR: emanshawky10@yahoo.com, EAM: ashraf.megahed@hotmail.com, NYS: noha.salem@vet.cu.edu.eg \\ Received: 16-08-2020, Accepted: 17-11-2020, Published online: 26-12-2020
}

doi: www.doi.org/10.14202/vetworld.2020.2780-2786 How to cite this article: Yehia SG, Ramadan ES, Megahed EA, Salem NY (2020) Effect of parity on metabolic and oxidative stress profiles in Holstein dairy cows, Veterinary World, 13(12): 2780-2786.

\begin{abstract}
Background and Aim: Pregnancy and lactation have an impact on health status of animals and constitute burden on body metabolites and the oxidant-antioxidant equilibrium. This study is aimed at evaluating metabolic and oxidative stress patterns and parity impacts in both primiparous and multiparous dairy cows.
\end{abstract}

Materials and Methods: Twenty-seven primiparous and multiparous Holstein cows were enrolled and categorized into four groups according to their physiologic status: Primiparous peripartum heifer $(n=5)$, primiparous postpartum cow ( $n=9)$, multiparous peripartum cows $(n=5)$, and multiparous postpartum cows $(n=8)$. Blood sample was taken from each animal peripartum groups at 3 weeks prepartum and postpartum groups at 3 weeks post-parturition - for complete blood picture, glucose, cholesterol, triglyceride, total protein, albumin, non-esterified fatty acids (NEFA), malondialdehyde (MDA), total antioxidant capacity, and haptoglobin estimation.

Results: Postpartum primiparous cows showed significant decrease in glucose, total protein, and albumin while showing significant increase in MDA, NEFA, and globulin; on the other hand, multiparous postpartum cows showed significant decrease in glucose, total protein, and albumin, associated with significant increase in cholesterol and MDA when compared with prepartum PP and MP cows, respectively. Postpartum multiparous cows significantly showed reduction in NEFA when compared to primiparous postpartum cows. Hematologic profiles of postpartum primiparous and multiparous cows showed significant decrease in red blood cells and packed cell volume, significant increase in lymphocytes when compared with prepartum cows.

Conclusion: Metabolic and oxidative abnormalities exist in both primiparous and multiparous cows during the transition phase, however postpartum primiparous cows show higher susceptibility to negative energy balance impacts. Oxidant/ antioxidant imbalance occurred in both the primiparous and multiparous postpartum cows, highlighting the importance of oxidative stress profiles in the assessment of metabolic health status during transition.

Keywords: haptoglobin, heifers, multiparous, non-esterified fatty acids, oxidative stress, transition.

\section{Introduction}

As previously defined, transition period is the time frame from 3 weeks before calving to 3 weeks after calving [1]. Transitioning cows then undergo numerous physiological and biochemical alterations, which act as stressors, and in turn, the cows become more vulnerable to several metabolic and infectious conditions [2,3]. During the period of early lactation and colostrum production, a cow's demand for energy and nutritional diet will significantly improve. This period is also crucial since it is usually associated with a reduction in food intake, and consequently, negative energy balance (NEB) is expected and mobilization of body fat in the form of non-esterified fatty acids (NEFA) will ensue [4].

Copyright: Yehia, et al. Open Access. This article is distributed under the terms of the Creative Commons Attribution 4.0 International License (http://creativecommons.org/licenses/by/4.0/), which permits unrestricted use, distribution, and reproduction in any medium, provided you give appropriate credit to the original author(s) and the source, provide a link to the Creative Commons license, and indicate if changes were made. The Creative Commons Public Domain Dedication waiver (http://creativecommons.org/ publicdomain/zero/1.0/) applies to the data made available in this article, unless otherwise stated.
Clinicopathological evaluation is one means of assessing dairy cow health status at the individual and herd level [5]. Several factors such as parity, stage of lactation, and season of production have substantial effects on milk production and blood parameters in clinically normal lactating cows [6]. One study found that the periparturient phase associated with liver inflammatory response is linked to mobilization of fats [4], leading to an increased lipid mobilization during the transition period due to the generation of reactive oxygen species (ROS) caused by NEB [7]. Although ROS are normal products of metabolic processes and are not generally harmful, it may lead to oxidative stress when found in greater amounts, or when produced at faster rates to an extent that antioxidant mechanisms can no longer mitigate them [8]. Haptoglobin (HP) is an acute-phase protein synthesized in the liver and could be used as a predictor of non-specific immune response caused by several inflammatory reactions [9]. NEB can lead to an increase in concentrations of HP around parturition [10]. Moreover, early lactation phase can cause 
tremendous loss in body fats in high producing dairy cows [1].

This study is aimed at evaluating the effects of parity on hematobiochemical and oxidative stress biomarkers as well as studying the metabolic and oxidative stress patterns in both primiparous and multiparous Holstein dairy cows during the transition phase.

\section{Materials and Methods}

\section{Ethical approval}

The research procedures conducted in this study were approved by the Institutional Animal Care and Use Committee (Approval code: Vet CU16072020178), Faculty of Veterinary Medicine, Cairo University, Egypt.

\section{Study period and location}

The study was conducted between September 2019 and December 2019. The samples were collected from Dairy farm in Fayoum Governate, Egypt and the laboratory investigations were conducted at Medicine and Infectious Diseases Department Laboratory, Faculty of Veterinary Medicine, Cairo University.

\section{Animals}

We enrolled 27 Holstein cows (weight: $450-700 \mathrm{~kg}$ and age: 2-6 years) into the study. Milk production and body condition scores (BCS) are depicted in Figure-1. Studied animals were categorized into four groups according to physiological status: (1) Primiparous peripartum group $(\mathrm{n}=5),(2)$ multiparous peripartum group $(n=5)$ : One sample was withdrawn from each animal 3 weeks preparturition, (3) primiparous postpartum group ( $\mathrm{n}=9$ ), and (4) multiparous postpartum group $(n=8)$ : One sample was withdrawn from each animal at $3^{\text {rd }}$ week postpartum.

Inclusion criteria included the following: Cows/ heifers with no prior clinical health issue and normal parturition without any adverse events and a BCS of 3 or more. Concerning multiparous cows, lactation period should be more than 200 days with an average milk production of more than $33 \mathrm{~L} /$ day.

\section{Samples and laboratory investigations}

Blood samples from each cow were collected on two tubes through tail vein. The first tube containing

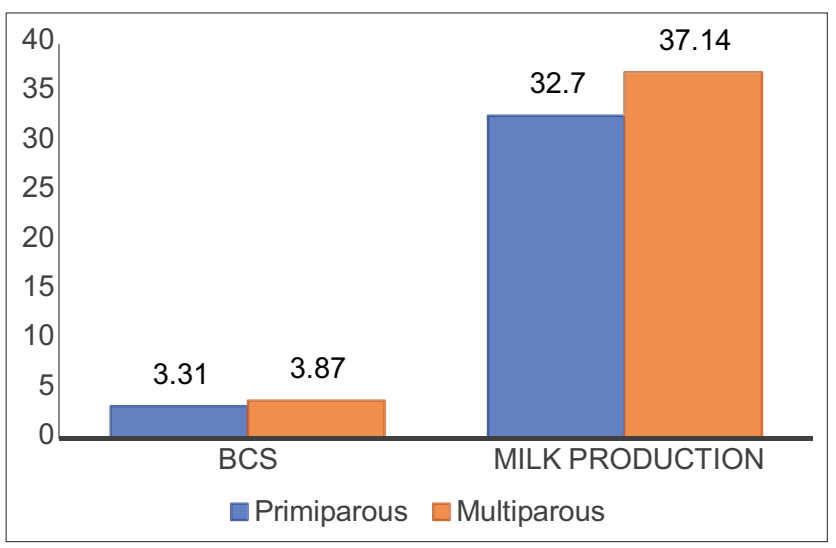

Figure-1: Body condition score and milk yield in primiparous and multiparous cows ethylenediaminetetraacetic acid was used for complete blood count using automated veterinary hematology analyzer. The second was a plain tube used for serum separation. Serum was then used to estimate glucose, cholesterol, triglyceride, total protein, and albumin (Spectrum Diagnostics, Egypt). NEFA was analyzed in all the collected serum samples (Randox, Cat no. FA115, UK). Malondialdehyde (MDA) and total antioxidant capacity (TAC) were estimated in the collected serum using dedicated test kits (Bio Diagnostic, Egypt). HP testing was done on serum samples (HP immunoturbidimetry) [11].

\section{Statistical analysis}

All quantitative data of hematology and metabolic and oxidative stress markers were presented as mean \pm standard error. The comparison was made using SPSS Statistics program version 16.0 (SPSS Inc. Released 2007. SPSS for Windows, Chicago) (independent samples t-test). $\mathrm{p} \leq 0.05$ was considered significant.

\section{Results}

\section{Serum biochemistry and oxidative stress markers}

When compared to the prepartum primiparous group, the postpartum primiparous cows showed a significant decrease in glucose, total protein, and albumin yet a significant increase in MDA, NEFA, and globulin (Table-1). Moreover, the multiparous postpartum group showed a significant decrease in glucose, total protein, and albumin, associated with a significant increase in cholesterol and MDA when compared with the prepartum multiparous group (Table-2). The findings also showed that the postpartum multiparous group showed a significant decrease in NEFA associated, with a non-significant increase in cholesterol, total protein, TAC, and MDA, compared to the primiparous postpartum group, in which the latter showing a non-significant increase in glucose (Table-3).

\section{Hematologic study}

Hematologic profiles of postpartum primiparous and multiparous cows demonstrated a significant decrease in red blood cell (RBC) count and packed cell volume (PCV) but a significant increase in lymphocytes and also showed a non-significant reduction in hemoglobin when compared to those of the prepartum groups (Tables-1 and 2). When compared to the postpartum primiparous cows, the multiparous cows revealed a non-significant decrease in RBCs and hemoglobin (Table-3).

\section{Milk yield and $\mathrm{BCS}$}

A significant increase in milk yield and BCS was found in the multiparous group compared to the postpartum primiparous group (Figure-1).

\section{Discussion}

The paper was aimed at elucidating the modifications in metabolic profile patterns of Holstein dairy cows during the transition period in both the primiparous and multiparous groups as well as assessing the 
Table-1: Metabolic, oxidative stress, and hematologic profile in primiparous cows before and after parturition.

\begin{tabular}{lcc}
\hline Parameter/unit & Peripartum primiparous group (n=5) & Postpartum primiparous group (n=9) \\
\hline Glucose $(\mathrm{mmol} / \mathrm{L})$ & $2.85 \pm 0.13$ & $2.11 \pm 0.25^{*}$ \\
NEFA $(\mathrm{mmol} / \mathrm{L})$ & $0.37 \pm 0.03$ & $0.91 \pm 0.12^{*}$ \\
Cholesterol (mmol/L) & $2.62 \pm 0.25$ & $2.82 \pm 0.34$ \\
Triglyceride (mmol/L) & $0.43 \pm 0.06$ & $0.44 \pm 0.07$ \\
Total Protein (g/L) & $69.3 \pm 1.4$ & $59.0 \pm 3.5^{*}$ \\
Albumin $(\mathrm{g} / \mathrm{L})$ & $34.8 \pm 1.2$ & $11.9 \pm 0.3^{*}$ \\
Globulin $(\mathrm{g} / \mathrm{L})$ & $32.5 \pm 1.3$ & $43.9 \pm 1.0^{*}$ \\
Haptoglobin $(\mathrm{Mmol} / \mathrm{L})$ & $2.2 \pm 0.5$ & $3.3 \pm 0.2$ \\
TAC $(\mathrm{mM} / \mathrm{L})$ & $0.68 \pm 0.16$ & $1.08 \pm 0.17$ \\
MDA $(\mathrm{nmol} / \mathrm{ml})$ & $1.54 \pm 0.36$ & $2.29 \pm 0.39^{*}$ \\
RBCs $\left(10^{12} / \mathrm{L}\right)$ & $8.53 \pm 0.44$ & $6.72 \pm 0.16^{*}$ \\
PCV $(\mathrm{L} / \mathrm{L})$ & $0.33 \pm 0.01$ & $0.28 \pm 0.02^{*}$ \\
HB $(\mathrm{g} / \mathrm{L})$ & $108.4 \pm 4.2$ & $102.2 \pm 6.2$ \\
WBCs $\left(10^{9} / \mathrm{L}\right)$ & $13.20 \pm 0.39$ & $16.48 \pm 1.43$ \\
Lymphocytes $\left(10^{9} / \mathrm{L}\right)$ & $6.74 \pm 0.26$ & $10.51 \pm 1.62^{*}$ \\
Neutrophils $\left(10^{9} / \mathrm{L}\right)$ & $5.30 \pm 0.27$ & $5.05 \pm 0.63$ \\
Platelets $\left(10^{9} / \mathrm{L}\right)$ & $252.50 \pm 18.80$ & $230.50 \pm 23.80$ \\
\hline
\end{tabular}

Data were presented as mean \pm standard error. $p \leq 0.05$ was considered significant. NEFA=Non-esterified fatty acids, TAC=Total antioxidant capacity, MDA=Malondialdehyde, RBCs=Red blood cells, PCV=Packed cell volume, $\mathrm{HB}=$ Hemoglobin, WBCs $=$ White blood cells

Table-2: Metabolic, oxidative stress, and hematologic profile in multiparous cows before and after parturition.

\begin{tabular}{lcc}
\hline Parameter/unit & Peri-partum multiparous group (n=5) & Postpartum multiparous group (n=8) \\
\hline Glucose $(\mathrm{mmol} / \mathrm{L})$ & $2.75 \pm 0.04$ & $1.81 \pm 0.23^{*}$ \\
NEFA $(\mathrm{mmol} / \mathrm{L})$ & $0.27 \pm 0.02$ & $0.34 \pm 0.05$ \\
Cholesterol $(\mathrm{mmol} / \mathrm{L})$ & $3.05 \pm 0.05$ & $3.59 \pm 0.21^{*}$ \\
Triglyceride (mmol/L) & $0.56 \pm 0.02$ & $0.43 \pm 0.07$ \\
Total Protein (g/L) & $78.4 \pm 5.1$ & $64.2 \pm 0.4^{*}$ \\
Albumin $(\mathrm{g} / \mathrm{L})$ & $35.8 \pm 0.4$ & $11.5 \pm 0.4^{*}$ \\
Globulin $(\mathrm{g} / \mathrm{L})$ & $42.5 \pm 5.1$ & $48.8 \pm 4.0$ \\
Haptoglobin $(\mathrm{mmol} / \mathrm{L})$ & $3.9 \pm 1.0$ & $3.1 \pm 0.03$ \\
TAC $(\mathrm{mM} / \mathrm{L})$ & $1.01 \pm 0.26$ & $1.26 \pm 0.003$ \\
MDA $(\mathrm{nmol} / \mathrm{ml})$ & $1.08 \pm 0.26$ & $2.52 \pm 0.31^{*}$ \\
RBCs $\left(10^{12} / \mathrm{L}\right)$ & $8.66 \pm 0.30$ & $6.43 \pm 0.20^{*}$ \\
PCV $(\mathrm{L} / \mathrm{L})$ & $0.34 \pm 0.004$ & $0.28 \pm 0.01^{*}$ \\
HB $(\mathrm{g} / \mathrm{L})$ & $113.8 \pm 2.3$ & $100.4 \pm 5.6$ \\
WBCs $\left(10^{9} / \mathrm{L}\right)$ & $12.23 \pm 0.45$ & $14.53 \pm 1.09$ \\
Lymphocytes $\left(10^{9} / \mathrm{L}\right)$ & $5.49 \pm 0.88$ & $8.80 \pm 0.65^{*}$ \\
Neutrophils $\left(10^{9} / \mathrm{L}\right)$ & $5.81 \pm 0.72$ & $4.40 \pm 0.18$ \\
Platelets $\left(10^{9} / \mathrm{L}\right)$ & $242.20 \pm 45.33$ & $229.20 \pm 16.67$ \\
\hline
\end{tabular}

Data were presented as mean \pm standard error. $p \leq 0.05$ was considered significant. NEFA=Non-esterified fatty acids, TAC=Total antioxidant capacity, MDA=Malondialdehyde, RBCs=Red blood cells, PCV=Packed cell volume, $\mathrm{HB}=$ Hemoglobin, WBCs $=$ White blood cells

consequences of parity on hematobiochemical parameters and oxidative stress biomarkers during the period of transition from pregnancy to lactation. Monitoring these alterations is highly crucial in evaluating the health status of herds as well as predicting the incidence of metabolic problems at this essential phase. Based on the study results, both the postpartum primiparous and multiparous groups showed alterations in different hematobiochemical parameters after parturition, and we observed that NEB was more evident in postpartum primiparous cows. Oxidant/antioxidant imbalance occurred in both postpartum primiparous and multiparous groups during the transition stage.

Metabolic profiling is essential in determining animal status. Parity, production season, and lactation stage are factors taken into account when assessing metabolic standpoint of dairy cows [6]. At early lactation stage, approximately $80 \%$ of blood constituents are essentially processed during milk production [12]. Hence, lactation has a strong impact on body storages and reserves in cows [13].

In this study, postpartum primiparous cows showed significant decrease in glucose, total protein, and albumin while revealing significant increase in MDA, NEFA, and globulin when compared to the prepartum primiparous group. The previous studies found higher NEFA concentrations in primiparous cows between 2 and 8 weeks postpartum $[14,15]$. However, another previous report has documented that NEFA concentration began to increase from 1-week prepartum until calving subsequently declining after parturition [16]. This indicates that the increase in NEFA in primiparous cows may be related to the energy demands of growth, load of the first lactation, and 
Table-3: Metabolic, oxidative stress, and hematologic profile in postpartum primiparous and multiparous cows.

\begin{tabular}{|c|c|c|}
\hline Parameter/unit & Postpartum primiparous group $(n=9)$ & Postpartum multiparous group $(n=8)$ \\
\hline Glucose (mmol/L) & $2.11 \pm 0.25$ & $1.81 \pm 0.23$ \\
\hline NEFA (mmol/L) & $0.91 \pm 0.12$ & $0.34 \pm 0.06 *$ \\
\hline Cholesterol (mmol/L) & $2.82 \pm 0.34$ & $3.59 \pm 0.21$ \\
\hline Triglyceride (mmol/L) & $0.44 \pm 0.07$ & $0.43 \pm 0.07$ \\
\hline Total Protein $(\mathrm{g} / \mathrm{L})$ & $59.0 \pm 3.5$ & $64.2 \pm 0.4$ \\
\hline Albumin $(\mathrm{g} / \mathrm{L})$ & $11.9 \pm 0.3$ & $11.5 \pm 0.4$ \\
\hline Globulin $(\mathrm{g} / \mathrm{L})$ & $43.9 \pm 1.0$ & $48.8 \pm 4.0$ \\
\hline Haptoglobin (mmol/L) & $3.3 \pm 0.2$ & $3.1 \pm 0.03$ \\
\hline TAC $(\mathrm{mM} / \mathrm{L})$ & $1.075 \pm 0.17$ & $1.26 \pm 0.003$ \\
\hline MDA $(\mathrm{nmol} / \mathrm{ml})$ & $2.29 \pm 0.39$ & $2.52 \pm 0.31$ \\
\hline $\operatorname{RBCs}\left(10^{12} / \mathrm{L}\right)$ & $6.72 \pm 0.16$ & $6.43 \pm 0.20$ \\
\hline $\mathrm{PCV}(\mathrm{L} / \mathrm{L})$ & $0.28 \pm 0.02$ & $0.28 \pm 0.01$ \\
\hline $\mathrm{HB}(\mathrm{g} / \mathrm{L})$ & $102.2 \pm 6.2$ & $100.4 \pm 5.6$ \\
\hline WBCs $\left(10^{9} / \mathrm{L}\right)$ & $16.48 \pm 1.43$ & $14.53 \pm 1.09$ \\
\hline Lymphocytes $\left(10^{9} / \mathrm{L}\right)$ & $10.51 \pm 1.62$ & $8.80 \pm 0.65$ \\
\hline Neutrophils $(10 \% / \mathrm{L})$ & $5.05 \pm 0.63$ & $4.40 \pm 0.18$ \\
\hline Platelets $\left(10^{9} / \mathrm{L}\right)$ & $230.50 \pm 23.80$ & $229.20 \pm 16.67$ \\
\hline
\end{tabular}

Data were presented as mean \pm standard error. $\mathrm{p} \leq 0.05$ was considered significant. NEFA=Non-esterified fatty acids, $T A C=$ Total antioxidant capacity, MDA=Malondialdehyde, RBCs=Red blood cells, PCV=Packed cell volume, $\mathrm{HB}=$ Hemoglobin, $\mathrm{WBC}=$ White blood cells

stressors of calving on these animals. Furthermore, studies support the fact that primiparous cows are more influenced by energy requirement deficits in the prepartum and postpartum periods $[17,18]$. The significant decrease of total protein during this phase occurs because ruminants utilize amino acids (from protein breakdown) as a vital fuel source for energy generation and synthesis [19].

In this study, hypoglycemia in postpartum primiparous cows was realized, which agrees with a previous study [16]. Increased demand for glucose to cope with the expected increase in milk production causes hypoglycemia during this phase [20]. In one study, glucose was thought of as an insensitive indicator of cattle energy status due to homeostatic regulation [5]; however, it was hypothesized that glucose in conjunction with NEFA and $\beta$-HBA is useful in indicating an animal's energy status [21].

Evaluation of the multiparous cows' metabolic profile pattern revealed significant decrease in glucose, total protein, and albumin, with significant increase in cholesterol and MDA, when compared to prepartum multiparous state. The reduction of glucose level in postpartum phase was also reported in other studies [16,20]. Increased glucose demand during early lactation, particularly in high-yielding animals, results in a hypoglycemic state [22]. NEB, associated with early lactation phase in high-yielding dairy cows, forces the animal's body to utilize its protein and fat reserve to compensate, which explains the reduction in total protein concentration after parturition [23].

Furthermore, significant increase in cholesterol in the post-parturition phase was noted in the multiparous group. This finding agreed with results of the previous studies stating that serum cholesterol concentration is comparatively higher in multiparous cows during early lactation, which contributes to fat mobilization that takes place during this time $[15,16,24,25]$. In addition, cholesterol concentration at the last days of pregnancy and around calving was relatively lower when compared to the amount of concentration during the $2^{\text {nd }}$ week of lactation due to increased needs during fetal development, in addition to the requirement of the ovaries for synthesis of steroid hormones [15,16,24,25]. The higher increase in cholesterol levels in multiparous cows could be associated with greater tissue mobilization, increased food intake, and more synthesis of steroid hormones and lipoproteins, which are normal physiological processes of the post-parturition phase [26,27].

In addition, in previous papers, comparison between postpartum primiparous and multiparous cows revealed non-significant differences in biochemical factors, including glucose, total protein, albumin, cholesterol, and triglycerides [20,25], which confirms the results found in the present paper.

When comparing postpartum primiparous with postpartum multiparous cows, the most striking result was the significant decrease in NEFA found in the latter group. Contradictory results were reported in the previous studies; however, some researchers asserted that NEFA changes are more pronounced in multiparous cows in the postpartum phase $[14,15,17]$. Other reports showed no significant differences in NEFA between multiparous and primiparous cows [20,25]. Furthermore, another paper stated that NEFA is more correlated with lactation stage than with parity [6]. The pervious investigators hypothesized that negative energy imbalance is more noticeable in primiparous heifers explained in their growth requirement, fetal development, and lactation, coupled with reduced appetite after parturition $[15,17,18]$.

Recently, an increasing interest in free-radical damage has been developed for the assessment of metabolic condition in transition cows. Under typical physiological circumstances, the body has a natural 
way of combating free radical build-up with the help of adequate antioxidants [8]. The MDA and TAC values in transition cows can reflect the physiological equilibrium during this phase [28]. The findings of the current study found that the level of MDA was significantly higher in both the primiparous and multiparous groups at postpartum period. The previous research studies consistently report similar findings [29-33]. MDA is produced from polyunsaturated fatty acid peroxidation and is used as an indicator for lipid peroxidation [34,35]. A significant mobilization of NEFA in dairy cows associated with increase in free oxygen radicals (e.g., ROS) production [36]. Increased free-radical production could be associated with the increase in MDA levels [37].

In the current study, TAC was selected to define the balance between pro-oxidants (MDA) and antioxidants [38]. Estimation of TAC could be used to give a rough indication of the antioxidant arm $[38,39]$. This study showed non-significant elevation in TAC in both postpartum primiparous and multiparous cows. Similar with a previous study, no correlation could be established between oxidant and antioxidant levels in postpartum cows [40]. Moreover, the highest level of TAC was recorded in dairy cow at the $8^{\text {th }}$ week of lactation [30]. This explains why production of peroxides exceeds the antioxidant system's capacity, considering the fact that these animals are predisposed to oxidative stress status, which might lead to negative impacts on their health status [41]. Oxidative stress status can occur because of massive oxidant output and/or depletion of defenses against oxidant attacks [42]. In relation to the outcomes presented in this study, we highlight the importance of oxidative stress profile along with metabolic profile in transition cows as a complementary tool in the assessment of metabolic status.

HP has been used recently as predictive indicator for clinical metritis, ketosis, and retained placenta occurrence at postpartum phase in dairy cows [43]. In the present study, no significant variations in HP concentration between the different groups were detected. Earlier articles have noted significant increase in HP concentration in the $1^{\text {st }}$ week postpartum [44]. Nevertheless, a previous report agreed with our results and found a non-significant increase in HP at the post-parturient period [45]. These differences might occur due to interindividual variability in the normal physiological acute phase response to parturition as some cows did not show any increase in HP concentrations at the early post-parturient phase [43]. In addition, a previous research assumed that primiparous cows that calve spontaneously might suffer from mild cervical or vaginal trauma after calving which remains unobserved clinically; however, stimulated inflammatory response is associated with greater HP concentrations. Nevertheless, another study noticed that an increase in HP concentration was associated with acute infection and not with noninfectious conditions and that the trauma of normal parturition did not cause increase in HP concentrations, suggesting that increase in HP is properly associated with infection and not trauma [46,47].

In the present investigation, both the primiparous and multiparous cases showed reduction in erythrogram in the form of reduction in PCV and RBCs postpartum compared to prepartum status. A negative correlation between milk production and PCV was postulated [48]. Furthermore, similar findings were observed in other ruminants as well [13]. Increased $\mathrm{RBC}$ destruction in mammary cells is associated with reduction in hematocrit [49]. One study found that the highest hemoglobin and PCV was found in non-pregnant heifers and the lowest values were found in lactating cows [50]. Erythrogram tended to decline at the early lactation phase and increased at the mid-lactation phase as noted in one study [51].

The observed increase in lymphocytes postpartum in both primiparous and multiparous cows could be attributed to migration of these cells to milk to boost immune defense rather than the possibility of microbial invasion to mammary cells and elevate phagocytic ability [52]. Changes in total leucocyte count and differential leucocyte count could be attributed to stress with consequent release of cortisol in the blood stream, which, in turn, increases the number of leukocytes in circulation [53]. Lymphocyte decrease at the final stage of gestation is associated with production of large amounts of adrenocorticoids in both the cow and the fetus [54]. Several factors in reducing leukocyte count in late pregnancy have been identified, for example, diet, hormonal level, and managemental strategies [55]. The effect of lactation leads to a wide variation in lymphocyte count [56]. Furthermore, the amount of leukocyte and lymphocyte produced is related to age and gestation duration [57].

The BCS is an easy and effective way of assessing body energy and adipose tissue stores in milk-yielding cows [58]. In this study, milk yield and BCS were found to be significantly higher in multiparous cows, which are consistent with other previous related studies $[14,15]$.

However, other authors have not established significant alterations in BCS between primiparous and multiparous cows at postpartum phase [17]. The fat stores in primiparous cows are lesser compared to those in multiparous cows, and their energy needs are greater due to continued growth. Consequently, energy requirements and utilization are different. Ultimately, physiological variations between primiparous and multiparous cows might influence body condition [14].

\section{Conclusion}

Based on the findings derived in this study, metabolic and oxidative modifications occur in both primiparous and multiparous cows during the transition stage; however, primiparous cows are more prone to NEB impacts, which are revealed in the increase in NEFA, 
compared to their multiparous counterparts. The oxidant/antioxidant imbalance recorded for the both postpartum primiparous and multiparous cows highlights the importance of utilizing oxidative stress profiling in conjunction with standard metabolic profile tests in evaluating metabolic health status in dairy cows.

\section{Authors' Contributions}

NYS and SGY designed the experiment. EAM performed Physical examinations and samples collection and processing. NYS, SGY, and ESR performed samples analysis. SGY performed data collection. NYS and ESR wrote the first draft. ESR performed Statistical analysis. NYS, SGY, and ESR: contributed in writing, organization and revision of the whole paper in final form.. All authors read and approved the final manuscript.

\section{Acknowledgments}

The authors would like to thank Enago ${ }^{\mathrm{TM}}$ (www. enago.com) for English language review. The authors would like to thank Department of Internal Medicine Laboratory, Faculty of Veterinary Medicine for providing facilities for this study. The authors did not receive any funds for this study.

\section{Competing Interests} interests.

The authors declare that they have no competing

\section{Publisher's Note}

Veterinary World remains neutral with regard to jurisdictional claims in published institutional affiliation.

\section{References}

1. Praveen, S. and Dhaarani, C. (2018) Managemental approach of the cow during transition period. Int. J. Sci. Environ., 7(3): 950-954.

2. Van Saun, R.J. (2016) Indicators of dairy cow transition risks: Metabolic profiling revisited. Tierarzt. Prax. Ausg. G Grosstiere Nutztiere, 44(2):118-126.

3. Weber, C., Schäff, C.T., Kautzsch, U., Börner, S., Erdmann, S., Görs, S., Röntgen, M., Sauerwein,xH., Bruckmaier, R.M., Metges, C.C., Kuhla, B. and Hammon, H.M. (2016) Insulin-dependent glucose metabolism in dairy cows with variable fat mobilization around calving. J. Dairy Sci., 99(8): 6665-6679.

4. Wankhade, P.R., Manimaran, A., Kumaresan, A., Jeyakumar, S., Ramesha, K.P., Sejian, V., Rajendran, D. and Varghese, M.R. (2017) Metabolic and immunological changes in transition dairy cows: A review. Vet. World, 10(11): 1367-1377.

5. Herdt, T.H. (2000) Variability characteristics and test selection in herd-level nutritional and metabolic profile testing. Vet. Clin. North Am. Food Anim. Pract., 16(2): 387-403.

6. Cozzi, G., Ravarotto, L., Gottardo, F., Stefani, A.L., Contiero, B., Moro, L., Brscic, M. and Dalvit, P. (2011) Short communication: reference values for blood parameters in Holstein dairy cows: Effects of parity, stage of lactation, and season of production. J. Dairy Sci., 94(8): 3895-3901.

7. Sordillo, L.M. and Raphael, W. (2013) Significance of metabolic stress, lipid mobilization, and inflammation on transition cow disorders. Vet. Clin. North Am. Food Anim.
Pract., 29(2): 267-278.

8. Halliwell, B. (2006) Reactive species and antioxidants. Redox biology is a fundamental theme of aerobic life. Plant Physiol., 141(2): 312-322.

9. Ceciliani, F., Ceron, J.J., Eckersall, P.D. and Sauerwein, H. (2012) Acute-phase proteins in ruminants. J. Proteomics, 75(14): 4207-4231.

10. Crawford, R.G., Leslie, K.E., Bagg, R., Dick, C.P. and Duffield, T.F. (2005) The impact of controlled release capsules of monensin on postcalving haptoglobin concentrations in dairy cattle. Can. J. Vet. Res., 69(3): 208-214.

11. Dati, F., Lammers, M., Adam, A., Sondag, D. and Stienen, L. (1989) Referenzwerte für 18 Plasmaproteine am BehringNephelometer-System. J. Lab Med., 13(3): 87-90.

12. Piccione, G., Caola, G., Giannetto, C., Grasso, F., Runzo, S.C., Zumo, A. and Pennisi, P. (2009) Selected biochemical serum parameters in ewes during pregnancy, post-parturition, lactation, and dry period. Anim. Sci. Pap. Rep., 27(4): 321-330.

13. Salem, N.Y. (2017) Effect of lactation on hemato-biochemical and minerals constituents in small ruminant. Int. J. Vet. Sci., 6(1): 53-56.

14. Meikle, A., Kulcsar, M., Chilliard, Y., Febel, H., Delavaud, C., Cavestany, D. and Chilibroste, P. (2004) Effects of parity and body condition at parturition on endocrine and reproductive parameters of the cow. Reproduction, 127(6): 727-737.

15. Colakoglu, H.E., Polat, I.M., Vural, M.R., Kuplulu, S., Pekcan, M., Yazlik, M.O. and Baklai, C. (2017) Associations between leptin, body condition score and energy metabolites in holstein primiparous and multiparous cows from 2 to 8 weeks postpartum. Rev. Méd. Vét., 168(4-6): 93-101.

16. Moreira, T.F., Filho, E.J.F., Meneses, R.M., Mendonça, F.L.M., Lima, J.A.M. and Carvalho, A.U. (2015) Energetic status of crossbreed dairy cows during transition period in two different seasons. Arq. Bras. Med. Vet. Zootec., 67(5): 1327-1334.

17. Wathes, D.C., Cheng, Z., Bourne, N., Taylor, V.J., Coffey, M.P. and Brotherstone, S. (2007) Differences between primiparous and multiparous dairy cows in the inter-relationships between metabolic traits, milk yield and body condition score in the periparturient period. Domest. Anim. Endocrinol., 33(2): 203-225.

18. Atashi, H., Zamiri, M.J. and Dadpasand, M. (2013) Association between dry period length and lactation performance, lactation curve, calf birth weight, and dystocia in Holstein dairy cows in Iran. J. Dairy Sci., 96(6): 3632-3638.

19. Allen, M.S. and Bradford, B.J. (2009) Control of eating by hepatic oxidation of fatty acids. A note of caution. Appetite, 53(2): 272-273.

20. Jasari, B., Celeska, B.A.I., Radeski, M., Nikolovski, M. and Dovenski, T. (2018) Metabolic profile and hormonal status comparison between primiparous and multiparous non-cyclic cows. Mac. Vet. Rev., 41(2): 195-201.

21. Adewuyi, A.A., Gruys, E., van Eerdenburg, F.J.C. (2005) Non-esterified fatty acids (NEFA) in dairy cattle. A review. Vet. Q., 27(3): 117-126.

22. White, H.M. (2015) The role of TCA cycle anaplerosis in ketosis and fatty liver in periparturient dairy cows. Animals, 5(3): 793-802.

23. Sammad, A., Wang, Y.J., Umer, S., Lirong, H., Khan, I., Khan, A., Ahmad, B. and Wang, Y. (2020) Nutritional physiology and biochemistry of dairy cattle under the influence of heat stress: Consequences and opportunities. Animals (Basel), 10(5): 793.

24. Saqib, M.N., Qureshi, M.S. and Khan, R.U. (2018) Changes in postpartum metabolites and resumption of ovarian cyclicity in primiparous and multiparous dairy cows. Appl. Biol. Chem., 61(1): 107-111.

25. Folnožić, I., Turk, R., Đuričić, D., Vince, S., Flegar-Meštrić, Z., Sobiech, P., Lojkić, M., Valpotić, H. and Samardžija, M. (2016) The effect of parity on metabolic 
profile and resumption of ovarian cyclicity in dairy cows. Vet. Arch., 86(5): 641-653.

26. Kaneko, J.J., Harvey, J.W. and Bruss, M.L. (2008) Clinical Biochemistry of Domestic Animals. $6^{\text {th }}$ ed. Academic Press, Burlington, MA.

27. Stengärde, L. (2010) Displaced Abomasum and Ketosis in Dairy Cows Blood Profiles and Risk Factors. 76f Thesis (Doctorate in Veterinary Medicine). Swedish University of Agricultural Sciences, Uppsala.

28. Castillo, C., Hernandez, J., Bravo, A., Lopez-Alonso, M., Pereira, V. and Benedito, J.L. (2005) Oxidative status during late pregnancy and early lactation in dairy cows. Vet. J., 169(2): 286-292.

29. Bernabucci, U., Ronchi, B., Lacetera, N. and Nardone, A. (2005) Influence of body condition score on relationships between metabolic status and oxidative stress in periparturient dairy cows. J. Dairy Sci., 88(6): 2017-2026.

30. Castillo, C., Hernandez, J., Valverde, I., Pereira, V., Sotillo, J., Lopez-Alonso, M. and Benedito, J.L. (2006) Plasma malonaldehyde (MDA) and total antioxidant status (TAS) during lactation in dairy cows. Res. Vet. Sci., 80(2): 133-139.

31. Turk, R., Juretic, D., Geres, D., Svetina, A., Turk, N. and Flegar-Mestric, Z. (2008) Influence of oxidative stress and metabolic adaptation on PON1 activity And MDA level in transition dairy cows. Anim. Reprod. Sci., 108(1-2): 98-106.

32. Sharma, N., Singh, N.K., Singh, O.P., Pandey, V. and Verma, P.K. (2011) Oxidative stress and antioxidant status during transition period in dairy cows. Asian Aust. J. Anim. Sci., 24(4): 479-484.

33. Omidi, A., Fathi, M.H. and Parker, M.O. (2017) Alterations of antioxidant status markers in dairy cows during lactation and in the dry period. J. Dairy Res., 84(1): 49-53.

34. Pavelescu, L.A. (2015) On reactive oxygen species measurement in living systems. J. Life Med., 8(1): 38-42.

35. Salem, N.Y., Yehia, S.G., Farag, H.S. and Elkhiat, M.A. (2016) Clinical, hemato-biochemical alterations and oxidant-antioxidant biomarkers in Babesia-infected calves. Int J. Vet. Sci. Med., 4(1): 17-22.

36. Senoh, T., Oikawa, S., Nakada, K., Tagami, T. and Iwasaki, T. (2019) Increased serum malondialdehyde concentration in cows with subclinical ketosis. J. Vet. Med. Sci., 81(6): 817-820.

37. Salem, N.Y., Abdel-Saeed, H., Farag, H.S. and Ghandour, R.A. (2020) Canine demodicosis: Hematological and biochemical alterations. Vet. World, 13(1): 68-72.

38. Ghiselli, A., Serafini, M., Natella, F. and Scaccini, C. (2000) Total antioxidant capacity as a tool to assess redox status: Critical view and experimental data. Free Radic. Biol. Med., 29(11): 1106-1114.

39. Abdel-Saeed, H. and Salem, N.Y. (2019) Evaluation of total antioxidant capacity, malondialdehyde, catalase, proteins, zinc, copper and IgE response in ovine verminous pneumonia. Int. J. Vet. Sci., 8(4): 255-258.

40. Castillo, C., Hernandez, J., Lopez-Alonso, M., Miranda, M. and Benedito, J.L. (2003) Values of plasma lipid hydroperoxides and total antioxidant status in healthy dairy cows: Preliminary observations. Arch. Anim. Breed., 46(3): 227-233.

41. Tan, B.L., Norhaizan, M.E., Liew, W.P. and Rahman, H.S. (2018). Antioxidant and oxidative stress: A mutual interplay in age-related diseases. Front. Pharmacol., 9(1162): 1-28.

42. Davies, K.J.A. (2000) Oxidative stress, antioxidant defenses, and damage removal, repair and replacement systems. Life, 50(4-5): 270-289.

43. Humblet, M.F., Guyot, H., Boudry, B., Mbayahi, F., Hanzen, C., Rollin, F. and Godeau, J.M. (2006) Relationship between haptoglobin, serum amyloid A, and clinical status in a survey of dairy herds during a 6-month period. Vet. Clin. Pathol., 35(2): 188-193.

44. Koets, A.P., De Schwartz, N. and Tooten, P. (1998) Release of proinflammatory cytokines related to luteolysis and the periparturient acute phase response in prostaglandin-induced parturition in cows. Theriogenology, 49(4): 797-812.

45. Skinner, J.G. (1992) Haptoglobin a Useful Marker for Detecting Periparturient Infection in Automated Metabolic Profile Screening. In: Proceedings of the $5^{\text {th }}$ Congress of the International Society for Animal Clinical Biochemistry, Parma, Italy. p133.

46. Burfeind, O., Sannmann, I., Voigtsberger, R. and Heuwieser, W. (2014) Receiver operating characteristic curve analysis to determine the diagnostic performance of serum haptoglobin concentration for the diagnosis of acute puerperal metritis in dairy cows. Anim. Reprod. Sci., 149(3-4): 145-151.

47. Skinner, J.G., Brown, R.A. and Roberts, L. (1991) Bovine haptoglobin in clinically defined field conditions. Vet. Rec., 128(7): 147-149.

48. Hassan, A.N., Al-Akkam, N. and Samak, M. (1982) Effects of various locational events and stage of pregnancy on locational trends, plasma hydrocortisone and blood hematology of cross-bred (Egyptian X Holstein) and buffalo (Bubalus bubalis) cows. World Rev. Anim. Prod., 18: 71-79.

49. Anwar, M.M., El-Din, A. and Taha, T.A. (2012) Changes in some hematological and serum biochemical parameters during the first week after lambing in six consecutive parities in some Egyptian sheep breeds. Egypt. J. Anim. Prod., 49(3): 293-302.

50. Sattar, A. and Mirza, R.H. (2009) Haematological parameters in exotic cows during gestation and lactation under subtropical conditions. Pak. Vet. J., 29(3): 129-132.

51. Das, H., Lateef, A., Panchasara, H.H. and Ali, M.A. (2016) Haemato-biochemical alterations during different stages of lactation in Mehshani buffaloes. Buffalo Bull., 35(3): 307-315.

52. Iriadam, M. (2007) Variation in certain hematological and biochemical parameters during the peri-partum period in Kilis does. Small Rumin. Res., 73(1-3): 54-57.

53. Müller, U., Kesser, J., Koch, C., Helfrich, H.P. and Rietz, C. (2019) Monitoring predictive and informative indicators of the energy status of dairy cows during early lactation in the context of monthly milk recordings using mid-infrared spectroscopy. Livest. Sci., 221 : 6-14.

54. Oliveira, W.D.C., Silva, T.P.D., Araujo, M.J., Edvan, R.L., Oliveira, R.L. and Bezerra, L.R. (2019) Changes in hematological biomarkers of Nellore cows at different reproductive stages. Acta Sci. Anim. Sci., 41(1): 1-7.

55. Halloz, H.F., Meliani, S., Benallou, B. and Ghazi, K. (2015) Hematological parameters during late gestation in Dairy cows raised in Tiaret, Algeria. Glob. Vet., 15(1): 45-47.

56. Coroian, C.O., Miresan, V., Coroian, A., Raducu, C., Andronie, L., Marchis, Z., Terhes, S. and Muntean, M.V. (2017) Biochemical and haematological blood parameters at different stages of lactation in cows. Bull. Univ. Agric. Sci. Vet. Med. Anim. Sci. Biotechnol., 74(1): 31-36.

57. Botezatu, A., Vlagioiu, C., Codreanu, M. and Orasanu, A. (2014) Biochemical and hematological profile in cattle effective. Bull. Univ. Agric. Sci. Vet. Med., 71(1): 27-30.

58. Souissi, W. and Bouraoui, R. (2019) Relationship between Body Condition Score, Milk Yield, Reproduction, and Biochemical Parameters in Dairy Cows, Lactation in Farm Animals Biology, Physiological Basis, Nutritional Requirements, and Modelization, Naceur M'Hamdi. IntechOpen, London. Available from: DOI: 10.5772/ intechopen. 85343 